\title{
INSECTICIDE MIXTURES FOR MOSQUITO NET IMPREGNATION AGAINST MALARIA VECTORS
}

\author{
CORBEL V.*, DARRIET F.*, CHANDRE F.** \& HOUGARD J.M.*
}

\section{Summary:}

Insecticides belonging to the pyrethroid family are the only compounds currently available for the treatment of mosquito nets. Unfortunately, some malaria vector species have developed resistance to pyrethroids and the lack of alternative chemical categories is a great concern. One strategy for resistance management would be to treat mosquito nets with a mixture associating two insecticides having different modes of action. This study presents the results obtained with insecticide mixtures containing several proportions of bifenthrin (a pyrethroid insecticide) and carbosulfan (a carbamate insecticide). The mixtures were sprayed on mosquito net samples and their efficacy were tested against a susceptible strain of Anopheles gambiae, the major malaria vector in Africa. A significant synergism was observed with a mixture containing $25 \mathrm{mg} / \mathrm{m}^{2}$ of bifenthrin (half the recommended dosage for treated netsl and $6.25 \mathrm{mg} / \mathrm{m}^{2}$ of carbosulfan (about $2 \%$ of the recommended dosage). The observed mortality was significantly more than expected in the absence of any interaction ( $80 \%$ vs $41 \%$ ) and the knock-down effect was maintained, providing an effective barrier against susceptible mosquitoes

KEY WORDS : insecticide mixture, synergy, treated mosquito net, Anopheles gambiae.

\section{INTRODUCTION}

I nsecticide-treated mosquito nets are strongly recommended for malaria control, especially in African countries which are severely affected by malaria (Line, 1996). Insecticides belonging to the pyrethroid family are the only compounds currently available for the treatment of mosquito nets. They ensure safe and effective protection because they act very rapidly, with both knockdown and lethal effects at dosages far below the threshold of mammalian toxicity (Zaim et al., 2000). Unfortunately, pyrethroid resistance has already developed in some populations of the major

* IRD, 911, avenue Agropolis, BP 64501, 34394 Montpellier cedex 5, France.

** CPR, 01 BP 1500, Bouaké 01, Côte d'Ivoire.

Correspondence: Jean-Marc Hougard, LIN/IRD, 911, avenue Agropolis, BP 64501, 34394 Montpellier Cedex 5, France.

Tel.: 33 (0)4670432 23 - Fax: 33 (0)467542044.
Résumé : LES MÉLANGES INSECTICIDES EN IMPRÉGNATION DE MOUSTIQUAIRES CONTRE LES VECTEURS DU PALUDISME

Les pyréthrinoïdes sont actuellement les seuls insecticides recommandés pour l'imprégnation des moustiquaires.

Malheureusement, la résistance aux pyréthrinoïdes est déjà apparue chez plusieurs espèces de vecteurs du paludisme menaçant ainsi l'efficacité de cette méthode de lutte. De plus, l'absence d'insecticide de remplacement pour l'imprégnation des moustiquaires reste un fait préoccupant. Une stratégie de gestion de la résistance consisterait à associer sur une moustiquaire deux insecticides ayant des modes d'action différents. Cette étude présente les résultats obtenus avec des moustiquaires imprégnées avec différentes proportions de bifenthrine (un pyréthrinoïde) et de carbosulfan (un carbamate). L'efficacité de ces moustiquaires biimprégnées a été testée sur des moustiques adultes sensibles d'Anopheles gambiae, principal vecteur du paludisme en Afrique. Un effet de synergie significatif a été détecté avec un mélange composé de $25 \mathrm{mg} / \mathrm{m}^{2}$ de bifenthrine lla moitié de la dose opérationnelle) et $6,25 \mathrm{mg} / \mathrm{m}^{2}$ de carbosulfan $12 \%$ de la dose opérationnelle). La mortalité observée a été significativement supérieure à celle attendue par sommation des effets $180 \%$ contre $41 \%$ et l'effet knock down a été maintenu, préservant ainsi une barrière efficace contre les moustiques.

MOTS CLÉS : mélange insecticides, synergie, moustiquaire imprégnée, Anopheles gambiae.

malaria vectors, particularly Anopheles gambiae s.s. in tropical Africa (Chandre et al., 1999). The lack of an alternative chemical category could jeopardize the effectiveness of treated mosquito nets against malaria transmission.

One strategy proposed for resistance management is the use of mixtures of pesticides with different mode of action (Tabashnik, 1989; Roush, 1993). This strategy imply that no cross resistance exist between the insecticides. For treated mosquito nets, this could be an insecticide mixture combining a pyrethroid insecticide with a non-pyrethroid insecticide such as carbamates or organophosphates. The use of an insecticide mixture is all the more promising if there is a positive interaction between the two components. This has been observed in crop protection and veterinary use with mixtures of pyrethroids with organophosphates or carbamates (Ali et al., 1977; Huges \& Trevethan 1979; Koziol \& Witkowski, 1982; Campanhola \& Plapp, 1989; Christian et al., 1986). A synergy has also been 
observed recently between a pyrethroid and a carbamate on susceptible and resistant larvae of Culex quinquefasciatus, a mosquito of medical importance (Corbel et al., 2002).

The present study is aimed to mosquito nets samples impregnated with insecticide mixtures combining low doses of pyrethroid and carbamate formulations ("bitreated" mosquito nets). Their efficacy were compared to "mono-treated" net samples on a susceptible strain of Anopheles gambiaes. s. Carbosulfan (2,3-dihydro-2,2dimetyl-7-benzofuranyl [(dibutylamino)thio] methylcarbamate) has been selected among carbamates. In contrast to pyrethroids and DDT, this insecticide family does not induce any knock-down effect. Carbosulfan is currently used for public health despite its relative toxicity to mammals because it has shown a good efficacy in net impregnation at $300 \mathrm{mg} / \mathrm{m}^{2}$, particularly against pyrethroid-resistant populations of Anopheles and Culex mosquitoes (Kolaczinski et al., 2000). Bifenthrin (2 methyl [1,1'-biphenyl]-3-yl)methyl 3-(2-chloro3,3,3-trifluoro-1-propenyl)-2,2-dimethyl-cyclopropanecarboxylate) has been selected among pyrethroids, as it is potentially a good candidate insecticide for malaria prevention. It is used world wide against a wide range of agricultural pests and has already been tested successfully under laboratory conditions against malaria vectors (Hougard et al., 2002). Preliminary field tests have confirmed its efficacy against pyrethroid-resistant populations of A. gambiae and C. quinquefasciatus at $50 \mathrm{mg} / \mathrm{m}^{2}$ (Guillet et al., 2001).

\section{MATERIAL AND METHODS}

T Tests were conducted using Kisumu, a fully susceptible reference strain of $A$. gambiae originated from Kenya and initially maintained under standard laboratory conditions $\left(27 \pm 2^{\circ} \mathrm{C}\right.$ and $80 \%$ relative humidity).

The net samples were impregnated with commercial formulations. Bifenthrin was formulated as a suspension concentrate (SC) containing $8 \%$ active ingredient (Talstar ${ }^{\circledR} 80$ SC, FMC, Philadelphia, USA). Carbosulfan was formulated as a microcapsule suspension containing $2.5 \%$ active ingredient (Marshall ${ }^{\circledR} 25$ CS, FMC, Philadelphia, USA).

The efficacy of insecticides, alone or in association, was assessed according to the cone test method (Anonymous WHO, 1998). Five unfed females aged from two to five days were placed in a plastic cone that was positioned over treated net sample. After three minutes the mosquitoes were removed from the net sample, placed in $150 \mathrm{ml}$ plastic cups and supplied with a $10 \%$ honey solution as a food source. The mosquitoes were held for 24 hours in an environmental chamber at $27^{\circ} \mathrm{C}$ $\pm 2^{\circ} \mathrm{C}$ and $80 \% \pm 10 \% \mathrm{RH}$. Each replicate consisted of three-four cones and each test sample was replicated three times. The percentage of knocked down mosquitoes was noted after a three minutes exposure on the treated net, at fixed time intervals, varying between two to 10 minutes according to the intensity of the knock down effect. The percentage mortality was recorded after 24 hours.

Data were analyzed using a log-probit program based on Finney (1971). The statistical analysis calculated the rates at which $50 \%$ and $95 \%$ of mosquitoes would be knock down (respectively: $\mathrm{KDt}_{50}$ and $\mathrm{KDt}_{95}$ ). The difference between two $\mathrm{KDt}_{50}$ or two $\mathrm{KDt}_{95}$ values was considered as statistically significant only if there is no overlap of their confidence limits. Each test was carried out with an untreated control mosquito net. If the control mortality was above $5 \%$, the "observed" mortality is adjusted by Abbott's formula (Abbott, 1925). Percent mortalities were compared using the Chi square test at a $95 \%$ Confidence Interval.

The netting material was a multifilament polyester 100 denier (weight in grams of $9.000 \mathrm{~m}$ yarn), mesh size $156\left(25\right.$ holes $\left./ \mathrm{cm}^{2}\right)$, from Siamdutch (Bangkok, Thailand). For treatment, pieces of netting were folded in three equal parts and put in a disposable petri dish. A volume of formulation suspension corresponding to specific absorbency of the net and prepared immediately before treatment was dropped regularly onto the surface. Net were then carefully soaked with fingers (fitted with plastic gloves) in order to ensure a regular distribution of the solution. Once impregnated, nets were kept to dry in the box. Tests were made five days after treatment in order to avoid testing deposits of markedly different ages, which might have different impact on mosquito behaviour and affect the results. We tested on Kisumu strain different impregnated nets with the insecticides alone and in mixtures with the objectives to find the better insecticide combination in term of $\mathrm{KdT}_{50 / 95}$ and mortality. Five samples of mosquito net were used as reference samples: two with bifenthrin alone at 25 and $12.5 \mathrm{mg} / \mathrm{m}^{2}$, three with carbosulfan alone at 100, 25 and $6.25 \mathrm{mg} / \mathrm{m}^{2}$, and one with no insecticide (control sample). Six other samples were impregnated with different bifenthrin / carbosulfan mixtures using the five doses enumerated above. These dosages have been selected as they induced separately a low range of mortality $(5 \%-40 \%)$, thus allowing a better detection of any synergism effect (Table I). By comparing the results observed with each mixture with the results theoretically expected in the absence of any interaction (un-correlated joint action), it was possible to determine the effect of such insecticide mixtures on adult mosquitoes The expected mortality was calculated by multiplying the percentage survival on each insecticide tested separately and subtracting the result from $100 \%$. In the same way, the KDt theoretically expected for a given insecticide mix- 
ture, in the absence of any interaction, is equal to the sum of the KDt of each insecticide. There is said to be synergy when the observed results are significantly higher than the expected results (positive interaction). There is said to be antagonism when the observed results are significantly lower than the expected results (negative interaction).

\section{RESULTS}

V alues shown in Table I were not adjusted since the control mortality was very low (no KD effect was observed with the untreated samples). The result obtained with carbosulfan alone confirmed the absence of $\mathrm{KD}$ effect that characterise the carbamate family, whatever the dosages tested. Results with bifenthrin alone confirmed the existence a KD effect, but there was no apparent dose/effect correlation since an overlap of the confidence intervals was observed for $\mathrm{KDt}_{50}$ as well as for $\mathrm{KDt}_{95}$. With these low concentrations, mortality levels recorded for each insecticide used separately were low (maximum $38 \%$ for bifenthrin and $15 \%$ for carbosulfan).

With insecticide mixtures, a reduction of the KD effect was noted when the dosage of carbosulfan increased and the dosage of bifenthrin decreased. This antagonism was more evident at the $\mathrm{KDt}_{95}$ levels, particularly with mixtures containing the lower dosage of bifenthrin $\left(12.5 \mathrm{mg} / \mathrm{m}^{2}\right)$ and the higher dosage of carbosulfan $\left(100 \mathrm{mg} / \mathrm{m}^{2}\right)$ : the speed of the KD effect was almost halved $\left(\mathrm{KDt}_{50}: 12.2 \mathrm{~min} ; \mathrm{KDt}_{95}: 50.6 \mathrm{~min}\right) \mathrm{com}-$ pared with that observed with bifenthrin alone at $12.5 \mathrm{mg} / \mathrm{m}^{2}\left(\mathrm{KDt}_{50}: 6.8 \mathrm{~min}\right.$; $\left.\mathrm{KDt}_{95}: 26.0 \mathrm{~min}\right)$. Conversely, a very significant synergy $(P<0.0001)$ was observed with the insecticide mixture containing the lower dosage of carbosulfan $\left(6.25 \mathrm{mg} / \mathrm{m}^{2}\right)$ and the higher dosage of bifenthrin $\left(25 \mathrm{mg} / \mathrm{m}^{2}\right)$ : the percentage mortality observed with the mixture $(80 \%)$ was twice the expected one in the absence of any interaction (41.1\%). Except for $12.5 \mathrm{mg} / \mathrm{m}^{2}$ bifenthrin and $100 \mathrm{mg} / \mathrm{m}^{2}$ carbosulfan, where a slight synergy was observed, no significant difference was noted with the other insecticide mixtures between the observed and expected mortalities.

\section{DISCUSSION}

The lack of knock down effect at low dosages of carbosulfan was confirmed. Results observed with the different mixtures showed that carbosulfan, at a relatively high dosage $\left(100 \mathrm{mg} / \mathrm{m}^{2}\right)$, could act as an inhibitor of the KD effect of pyrethroids. The irritant properties of carbosulfan against Anopheles and Mansonia species was demonstrated by Klein et Darriet (1989) by house spraying of experimental huts. At a relatively high dosage, the irritant effect of carbosulfan could decrease the duration of tarsal contact with the substrate, thus reducing the KD effect of bifenthrin.

Regarding mortality, a very significant synergy $(P<$ $0.0001)$ was noted at the highest dosage of bifenthrin $\left(25 \mathrm{mg} / \mathrm{m}^{2}\right)$ and the lowest of carbosulfan $\left(6.25 \mathrm{mg} / \mathrm{m}^{2}\right)$. Although these insecticides do not have the same target sites, it is likely that their combination resulted in a complex molecular interaction. Pyrethroids act on the nervous system by modifying the gating kinetics of voltage-sensitive sodium channels (Lund \& Narahashi, 1983). As with the other pyrethroids, bifenthrin keeps the sodium channels open temporarily, thus cau-

\begin{tabular}{|c|c|c|c|c|c|c|c|c|c|c|c|}
\hline \multirow[b]{2}{*}{ Insecticide } & \multicolumn{4}{|c|}{$\mathrm{KDt}_{50}(\mathrm{~min})$} & \multicolumn{3}{|c|}{$\mathbf{K D t}_{95}(\mathrm{~min})$} & \multicolumn{4}{|c|}{ Mortality (\%) } \\
\hline & $\mathrm{N}$ & Observed & $\mathrm{Cl}$ & Expected & Observed & $\mathrm{Cl}$ & Expected & Observed & Expected & $\chi^{2}$ & $P$ \\
\hline \multicolumn{12}{|l|}{ Bifenthrin } \\
\hline $25 \mathrm{mg} / \mathrm{m}^{2}$ & 61 & 6.0 & $5.2-6.8$ & - & 26.8 & $21.2-37.8$ & - & 38.0 & - & - & - \\
\hline $12.5 \mathrm{mg} / \mathrm{m}^{2}$ & 58 & 6.8 & $6.0-7.6$ & - & 26.0 & $21.5-33.7$ & - & 26.0 & - & - & - \\
\hline \multicolumn{12}{|l|}{ Carbosulfan } \\
\hline $100 \mathrm{mg} / \mathrm{m}^{2}$ & 51 & no efect & - & - & no effect & - & - & 15.0 & - & - & - \\
\hline $25 \mathrm{mg} / \mathrm{m}^{2}$ & 52 & no effect & - & - & no effect & - & - & 4.0 & - & - & - \\
\hline $6.25 \mathrm{mg} / \mathrm{m}^{2}$ & 50 & no effcet & - & - & no effcet & - & - & 5.0 & - & - & - \\
\hline \multicolumn{12}{|l|}{ Bifenthrin $25 \mathrm{mg} / \mathrm{m}^{2}$} \\
\hline + Carbo. $100 \mathrm{mg} / \mathrm{m}^{2}$ & 59 & 8.0 & $6.9-9.0$ & 6.0 & 42.8 & $34.1-58.6$ & 26.8 & 37.0 & 47.3 & 1.2 & $>0.05$ \\
\hline + Carbo. $25 \mathrm{mg} / \mathrm{m}^{2}$ & 62 & 5.7 & $4.8-6.6$ & 6.0 & 30.2 & $23.9-42.3$ & 26.8 & 53.0 & 40.5 & 2.1 & $>0.05$ \\
\hline + Carbo. $6.25 \mathrm{mg} / \mathrm{m}^{2}$ & 60 & 5.4 & $4.6-6.1$ & 6.0 & 20.7 & $17.6-25.6$ & 26.8 & 80.0 & 41.1 & 18.5 & $<0.05$ \\
\hline \multicolumn{12}{|l|}{ Bifenthrin $12.5 \mathrm{mg} / \mathrm{m}^{2}$} \\
\hline+ Carbo. $100 \mathrm{mg} / \mathrm{m}^{2}$ & 64 & 12.2 & $11.1-13.4$ & 6.8 & 50.6 & $41.1-68.1$ & 26.0 & 56.0 & 37.1 & 4.5 & $<0.0001$ \\
\hline + Carbo. $25 \mathrm{mg} / \mathrm{m}^{2}$ & 63 & 7.7 & $6.8-8.4$ & 6.8 & 26.2 & $22.5-32.1$ & 26.0 & 35.0 & 29.0 & 0.6 & $>0.05$ \\
\hline + Carbo. $6.25 \mathrm{mg} / \mathrm{m}^{2}$ & 63 & 6.1 & $5.3-7.0$ & 6.8 & 29.3 & $24.8-42.4$ & 26.0 & 46.0 & 29.7 & 3.4 & $>0.05$ \\
\hline
\end{tabular}

$\mathrm{N}$, number tested. $\mathrm{Cl}, 95 \%$ confidence interval. Percent mortalities were compared using a Chi square test at $95 \%$ confidence interval.

Table I. - Compared activity of bifenthrin and carbosulfan formulations, alone and in association, against susceptible Anopheles gambiae. 
sing repeated discharges of action potentials which increase the amount of acetylcholine (ACh) in the synapses (Salgado, 1983). Carbosulfan, as with the other carbamates, is an inhibitor of acetylcholineterase (AChE). Such inhibition also contributes to increased ACh concentration at level which could explain the synergy observed. The absence of synergy at higher concentrations of carbosulfan could be due either to the shorter contact between mosquitoes and impregnated nets, as observed by reduced $\mathrm{KD}$ effect, or to a secondary target site inhibition as Choline Acetyltransferase (ChAT). ChAT is a protein implicated in synthesis of ACh and is a secondary target for carbamates (Bourguet et al., 1997). When adding a higher dosage of carbosulfan $\left(100 \mathrm{mg} / \mathrm{m}^{2}\right)$, ChAT could become an insecticide target, leading to a decrease of ACh production which could balance the accumulation of $\mathrm{ACh}$ due to the other mechanisms.

Because carbamates are potent inhibitors of $\mathrm{ACh}$ and because carbosulfan degrades to a more toxic compound (carbofuran) (2,3-dihydro-2,2-dimethyl-n-7-benzofuranyl methylcarbamate) by the loss of the (dibutylamino)thio group, the toxicological risk of their use on mosquito nets has to be carefully considered in relation to human safety (Anonymous WHO, 1986). It is encouraging that the optimum interaction obtained in the susceptible Kisumu strain was with the lower dose of carbosulfan (about 50 times less than the operational dose). However, an insecticide mixture must be considered as a new compound that needs a long series of toxicological studies before it would be cleared for use on mosquito nets (Zaim et al., 2000). Another important advantage with this ratio was the absence of any antagonism of the KD effect that allows the mixture to keep its fast acting properties on nets and continue to provide an effective barrier against susceptible mosquitoes (Miller \& Gibson, 1994).

Preliminary field studies in experimental huts have been carried out in Côte d'Ivoire by using a "two in one" combination of bifenthrin and carbosulfan applied to different parts of the same bednet (Guillet et al., 2001). Promising results have been obtained against the local pyrethroid resistant populations of A. gambiaes.s. and $C$. quinquefasciatus. This study will be completed in the same area by using mosquito nets treated with a mixture of bifenthrin and carbosulfan at an optimum ratio giving mortality under laboratory conditions.

\section{ACKNOWLEDGEMENTS}

W e thank the Ministère français de la recherche on malaria and associated communicable diseases for developing countries
( $\mathrm{PAL}^{+}$program) for funding this work and the FMC Corporation for providing the formulations of bifenthrin and carbosulfan.

\section{REFERENCES}

Аввотт W.S. A method of computing the effectiveness of an insecticide. Journal of Economic Entomology, 1925, 18, 265-267.

Ali J.N., Ali M., Hornyak E.P. \& Weaver J.B. Joint action of two pyrethroids with methyl-parathion, methomyl, and chlorpyrifos on Heliothis zea and H. virescens in the laboratory and in the cotton and sweetcorn. Journal of ECOnomic Entomology, 1977, 7, 813-817.

AnOnymous. Carbamate insecticides: a general introduction. WHO mimeographed document Environmental Health Criteria 64, Geneva: WHO, 1986.

Anonymous. Test procedures for insecticide resistance monitoring in malaria vectors, bio-efficacy and persistence of insecticides ion treated surfaces. WHO mimeographed document WHO/CDS/MAL/98.12, Geneva: WHO, 1998.

Bourget D., Raymond M., Berrada S. \& Fournier D. Interaction between acetycholinesterase and choline acetyltransferase: an hypothesis to explain unusual toxicology responses. Pesticide Science, 1997, 51, 276-282.

Campanhola C. \& Plapp F.W. Toxicity and synergism of insecticides against susceptible and pyrethroid-resistant third instars of the Tobacco Budworm (Lepidoptera: Noctuidae). Journal of Economic Entomology, 1989, 82, 1495-1501.

Chandre F., Darriet F., Manga L., Akogbeto M., Faye O., MouCHET J. \& Guillet P. Status of pyrethroid resistance in Anopheles gambiae sensu lato. Bulletin of the World Health Organization, 1999, 77, 230-234.

Christian M.L., Owens J.C., Lewis B.E. \& Davis F.M. Interactions studies of methyl parathion, carbofuran, permethrin, and piperonyl butoxide applied to southwestern corn borer larvae (Lepidoptera: Pyralidae). Journal of economic Entomology, 1986, 79, 549-552.

Corbel V., Chandre F., Darriet F., Lardeux F. \& Hougard J.M. Synergistic activity between permethrin and propoxur against Culex pipiens quinquefasciatus larvae. Medical and Veterinary Entomology, 2002, 16, in press.

FInNEy D.J. Probit analysis. Cambridge University Press, Cambridge, 1971, $333 \mathrm{pp}$.

Guillet P., N'Guessan R., Darriet F., Traoré-Lamizana M., Chandre F. \& Carnevale P. Combined pyrethroid and carbamate "two in one" treated mosquito nets: field efficacy against pyrethroid-resistant Anopheles gambiae and Culex quinquefasciatus. Medical and Veterinary Entomology, 2001, 15, 105-112.

Hougard J.M., Duchon S., Zaim M. \& Guillet P. Bifenthrin: a useful pyrethroid insecticide for treatment of mosquito nets. Journal of Medical Entomology, 2002, 39, 526-533.

Hughes P.B. \& Trevethan P. Laboratory and semi field evaluation of chlorfenvinphos-cypermethrin mixtures against larvae of the sheep Blowfly Lucilia cuprina (Wiedmann). Genetic and Apply Entomology, 1979, 11, 18-20. 
KLEIN J.M. \& DARRIET F. Evaluation en phase II du carbosulfan en aspersion intradomiciliaire contre les moustiques sauvages Anopheles et Mansonia à la station expérimentale de Soumousso, Burkina Faso. WHO mimeographed document WHO/VBC/89.968, Geneva: WHO, 1989.

Kolaczinski J.H., Fanello C., Hervé J.-P., Conway D.J., CarNEVALE P. \& CuRTis C.F. Experimental and molecular genetic analysis of the impact of pyrethroid and non pyrethroid insecticide impregnated bednets for mosquito control in an area of pyrethroid resistance. Bulletin of entomological Research, 2000, 90, 125-132.

KozıOL S.F. \& WITOWSKI J.F. Synergism studies with binary mixtures of permethrin plus methyl parathion, chlorpyrifos, and malathion on European corn borer larvae. Journal of Economic Entomology, 1982, 75, 28-30.

LiNE J. Mosquito nets and insecticides for net treatment: a discussion of existing and potential distribution systems in Africa. Tropical Medicine and International Health, 1996, 1, 616-632.

Lund A.E. \& NARAHASHI T. Kinetics of sodium channel modification as the basis for the variation in the nerve membrane effects of pyrethroid and DDT analogs. Pesticide and Biochemical Physiology, 1983, 20, 203-216.

Miller J.E. \& Gibson G. Behavioural response of host-seeking mosquitoes (Diptera: Culicidae) to insecticide-impregnated bed netting: a new approach to insecticide bioassay. Journal of Medical Entomology, 1994, 31, 114-122.

RousH R.T. Occurrence, genetics and management of insecticide resistance. Parasitology Today, 1993, 9, 174-179.

Salgado V.L., Irving S.N. \& Miller T.A. The importance of nerve terminals depolarization in pyrethroid poisoning insects. Pesticide Biochemistry and Physiology, 1983, 20, 169-182.

TABAshnik B.E. Managing Resistance with multiple Pesticide Tactics: Theory, Evidence, and Recommendations. Journal of Economic Entomology, 1989, 825, 1263-1269.

Zaim M., Aitio A. \& NAKASHIma N. Safety of pyrethroid-treated nets. Medical and Veterinary Entomology, 2000, 14,1-5.

Reçu le 15 avril 2002 Accepté le 13 mai 2002 